\title{
Stereotactic body radiation therapy for stage I non-small cell lung cancer: a small academic hospital experience
} \author{
Alicia E. Gittleman ${ }^{1}$, Donna T. Catell ${ }^{1}$ and Jonathan A. Haas ${ }^{1}{ }^{*}$ \\ ' Division of Radiation Oncology, Winthrop-University Hospital, New York, NY, USA \\ 2 Stony Brook School of Medicine, New York, NY, USA \\ ${ }^{3}$ Division of Medical Oncology, Winthrop-University Hospital, New York, NY, USA \\ ${ }^{4}$ Department of Thoracic and Cardiovascular Surgery, Winthrop-University Hospital, New York, NY, USA
}

Oren B. Factor ${ }^{1,2}$, Charles C. Vu ${ }^{2}$, Jeffrey G. Schneider ${ }^{3}$, Matthew R. Witten ${ }^{1}$, Scott L. Schubach ${ }^{4}$,

\section{Edited by:}

Brian Timothy Collins, MedStar

Georgetown University Hospital, USA

Reviewed by:

Keith Unger, MedStar Georgetown

University Hospital, USA

Sonali Rudra, MedStar Georgetown

University Hospital, USA

*Correspondence:

Jonathan A. Haas, Division of

Radiation Oncology,

Winthrop-University Hospital, 264 Old

Country Road, Mineola, New York, NY

11501, USA

e-mail: jhaas@winthrop.org
Purpose/Objective(s): Stereotactic body radiation therapy (SBRT) has been shown to have increased local control and overall survival relative to conventional external beam radiation therapy in patients with medically inoperable stage I non-small cell lung cancer (NSCLC). Excellent rates of local control have been demonstrated both in clinical trials and in single-center studies at large academic institutions. However, there is limited data on the experiences of small academic hospitals with SBRT for stage I NSCLC. The purpose of this study is to report the local control and overall survival rates in patients treated with SBRT for stage I NSCLC at Winthrop-University Hospital (WUH), a small academic hospital.

Materials/Methods: This is a retrospective review of 78 stage I central and peripheral NSCLC tumors treated between December 2006 and July 2012 with SBRT at WUH. Treatment was given utilizing fiducials and a respiratory tracking system. If the fiducials were not trackable, a spine tracking system was used for tumor localization. CT-based planning was performed using the ray trace algorithm. Treatment was delivered over consecutive days to a median dose of $4800 \mathrm{cGy}$ delivered in four fractions. The Kaplan-Meier method was used to calculate local control and overall survival.

Results: The median age was 78.5 years. Fifty-four percent of the patient population was female. Sixty seven percent of the tumors were stage IA, and $33 \%$ of the tumors were stage IB. Fifty-three percent of the tumors were adenocarcinomas and $29 \%$ were squamous cell carcinomas, with the remainder being of unknown histology or NSCLC, not otherwise specified The 2-year local control rate was $87 \%$, and the 2-year overall survival was $68 \%$.

Conclusion: Our findings support that local control and overall survival at a small academic hospital are comparable to that of larger academic institutions' published experiences with SBRT for stage I NSCLC.

Keywords: SBRT, non-small cell lung cancer, SABR, CyberKnife, local control, overall survival

\section{INTRODUCTION}

Surgery is the standard of care for stage I non-small cell lung cancer (NSCLC) (1) with local recurrence rates quoted around 5\% $(2,3)$ and 5 -year overall survival from 75 to $80 \%$ (4). In patients, who are medically inoperable or refuse surgery, radiation therapy is the next line treatment. Local control and overall survival with conventional radiation therapy have been demonstrated to be substantially inferior to surgery (5). Local control with conventional radiation therapy is reported from 40 to $70 \%$ with 5 -year overall survival quoted from 7 to $32 \%$ (5).

Stereotactic body radiation therapy (SBRT) is becoming the standard of care in medically inoperable patients with stage I NSCLC (1). SBRT has been shown to be superior to conventional radiation therapy with local control from 83 to $93 \%$ and 3 -year overall survival from 47 to $84.7 \%(4,6-10)$. Most of the data from SBRT have come from clinical trials and single-center studies at large academic institutions. Data from smaller academic hospitals are more limited. The goal of this paper is to report the local recurrence rate and overall survival of patients with stage I NSCLC treated with SBRT at our institution. Additionally, this study performs an analysis of the patient, tumor, and treatment characteristics that predict local control and overall survival.

\section{MATERIALS AND METHODS PATIENT POPULATION}

This is a retrospective review of 78 stage I central and peripheral NSCLC tumors in 74 patients treated between December 2006 and July 2012 with SBRT at Winthrop-University Hospital (WUH). Peripheral tumors were defined at those $>2 \mathrm{~cm}$ in all directions around the proximal bronchial tree. Patients 
who received CyberKnife for stage I NSCLC were identified from a WUH lung tumor registry. Patients were either medically inoperable or refused surgery. All patients were seen in conjunction with the Chairman of Thoracic Surgery to determine eligibility as to operability. It is primarily the decision of the Thoracic Surgeon who determines if a patient is a candidate for resection although the pulmonologist is often consulted. All patients had a PET/CT scan prior to treatment for staging purposes. As a general rule, PFTs were also obtained primarily to determine resectability. No patient had a FEV-1 $<0.61$. Patients who received chemotherapy or mediastinal radiation were excluded. All patients' radiation oncology records were subsequently reviewed. This study was approved by our hospital's institutional review board.

\section{TREATMENT TECHNIQUE}

All 78 tumors were treated using a CyberKnife robotic linear accelerator. All patients were immobilized using a thermoplastic cast with arms up. One fiducial marker was placed at least 5 days prior either using CT guidance or navigational bronchoscopy to account for seed migration. CT imaging was performed using $1.5 \mathrm{~mm}$ cuts. Planning was performed using Multiplan (Accuray, Inc., Sunnyvale, CA, USA) inverse planning and delivered using the CyberKnife (Accuray, Inc.) with motion and respiratory tracking performed using the Synchrony system (Accuray, Inc.). For six tumors, the fiducials were not trackable, and a spine tracking system was used for tumor localization. The planning target volume (PTV) was created by adding a 5-mm margin to the GTV. In general, treatment was delivered over four consecutive days for central tumors to a dose of $4800 \mathrm{cGy}$ delivered in four fractions (11). Peripheral tumors were treated to a dose of $6000 \mathrm{cGy}$ in three consecutive fractions (6). The median dose delivered for all patients was $4800 \mathrm{cGy}$ in four fractions. The various dose fractionation schemes are listed in Table 1. Patients treated with alternative dose fractionation schemes received prior radiation therapy. $\mathrm{BED}_{10 \mathrm{~Gy}}$ was calculated for each of our dose schedules using the formula $n d(1+d / \alpha / \beta)$, where $n$ is the fractionation number, $d$ is the daily dose, and $\alpha / \beta$ is assumed to be 10 for tumors. Tissue corrections and dose heterogeneity corrections were used in the treatment planning process. Dose constraints for normal tissues were the same as those used in RTOG 0236 (6).

\section{FOLLOW-UP}

The primary endpoints of this study were local control, overall survival, and toxicities. Recurrence-free survival was also evaluated. Local failure was defined as tumor recurrence within or immediately adjacent to the treated field. Local control was defined as the absence of local failure. Recurrence-free survival was defined as the time from the end of treatment to occurrence of a local failure, mediastinal relapse, distant relapse, or death. Patients were followed up periodically using either CT scans or combined PET/CT scans. The most recent CT scan, PET/CT scan, or time to local failure was noted. Overall survival was determined by the most recent follow-up or time to death. Follow-up was based primarily on the radiation oncology records. In addition, any supplemental notes from other departments sent to the radiation oncology department were also used. Overall survival was confirmed using the social security death index.
Table 1 | Dose fractionation schemes

\begin{tabular}{lcr}
\hline Dose & Number of patients & $\%$ \\
\hline $30(15 \times 2)$ & 1 & 1 \\
$32(8 \times 4)$ & 1 & 1 \\
$40(10 \times 4)$ & 2 & 3 \\
$40(8 \times 5)$ & 1 & 1 \\
$45(15 \times 3)$ & 14 & 18 \\
$48(12 \times 4)$ & 39 & 50 \\
$60(15 \times 4)$ & 5 & 6 \\
$60(20 \times 3)$ & 15 & 19 \\
\hline
\end{tabular}

\section{STATISTICAL ANALYSIS}

Actuarial local control, overall survival, and recurrence-free survival were calculated using the Kaplan-Meier method. Univariate analysis was performed using Cox regression. Factors analyzed in the univariate analysis included $\mathrm{BED}_{10 \mathrm{~Gy}}$, gender, age, and T-stage. A BED 10 Gy cut off of 106 Gy was used in the univariate analysis because this was the median $\mathrm{BED}_{10 \mathrm{~Gy}}$ in this study. All statistical analysis was done in SPSS 21 (IBM, Armonk, NY, USA). Toxicity was determined using the CTCAE 4.0 classification.

\section{RESULTS}

Demographic, tumor, and treatment characteristics are as follows: the median age was 78.5 years (range $56-93$ years). Thirty-six tumors $(46 \%)$ were in male patients and 42 tumors (54\%) were in female patients. Thirty-four tumors $(44 \%)$ were peripherally located and 44 tumors (56\%) were centrally located. Forty-one tumors (53\%) were adenocarcinoma, 23 tumors (29\%) squamous cell carcinoma, 10 tumors (13\%) NSCLC, not otherwise specified, and 4 tumors $(5 \%)$ had unknown histology. Fifty-two tumors $(67 \%)$ were T1 and 26 tumors (33\%) were T2.

The median follow-up for local control was 14.4 months. A total of seven local failures occurred in this study. The median time to local failure was 17 months with a range from 5 to 53 months. The 2 -year local control rate was $87 \%$ (Figure 1). Median follow-up for overall survival was 18.8 months. The 2-year overall survival was $68 \%$ in this patient population (Figure 2). There were 16 cases (22\%) of mediastinal failure, and 10 cases (14\%) of distant metastases. There were 25 cases (34\%) of recurrence of any form. The 2-year recurrence-free survival was $48.3 \%$ (Figure 3 ).

Table 2 summarizes the univariate analysis of patient, tumor, and treatment characteristics on 2-year local recurrence and overall survival. Only male gender $(p=0.009)$ was associated with worse overall survival. Other patient, tumor, or treatment factors, including age, histology, T-stage, and biologic equivalent dose $\left(\mathrm{BED}_{10 \mathrm{~Gy}}\right)$, did not predict overall survival. No factors, including patient gender, were able to predict local recurrence.

There was one case of grade 2 pneumonitis identified. There were no reported cases of radiation pneumonitis greater than grade 2 . There were no other toxicities experienced in this study.

\section{DISCUSSION}

Clinical trials as well as single-center studies have shown SBRT to provide far superior local control and overall survival when compared to conventional radiation therapy in the treatment of 


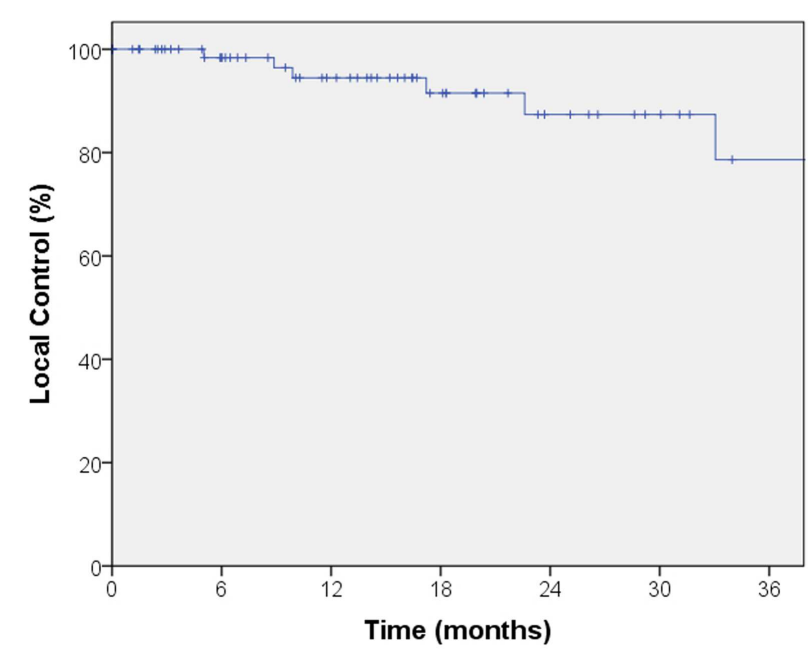

FIGURE 1 | Kaplan-Meier curve for local control. The median follow-up for local control was 14.4 months. A total of seven local failures occurred in this study. The median time to local failure was 17 months with a range from 5 to 53 months. The 2-year local control rate was $87 \%$.

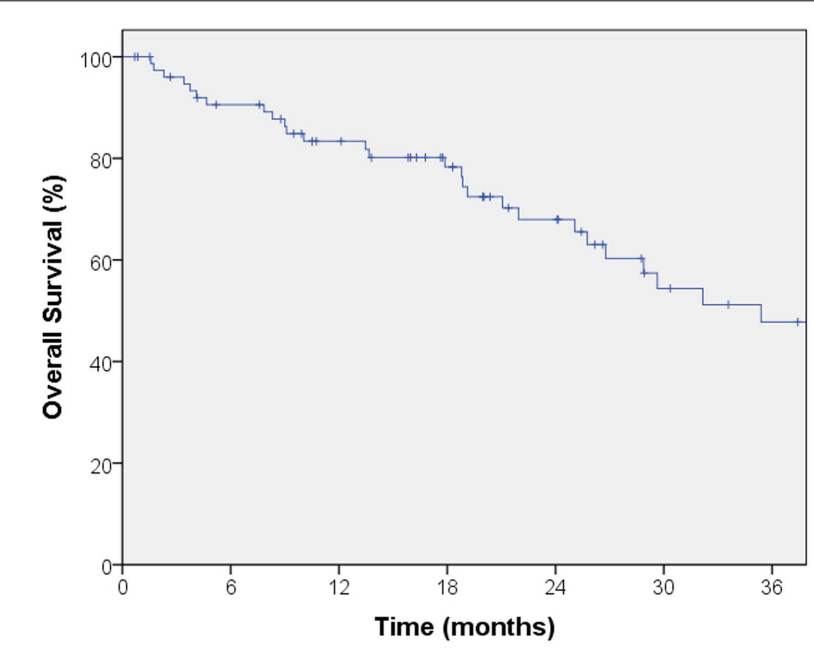

FIGURE 2 | Kaplan-Meier curve for overall survival. Median follow-up for overall survival was 18.8 months. The 2 -year overall survival was $68 \%$ in this patient population.

clinically inoperable stage I NSCLC, establishing SBRT as the standard of care in these patients $(1,6-10)$. The 2 -year overall survival $(68 \%)$ and 2-year local control (87\%) in this study are similar to clinical trials and studies at larger academic institutions. Table 3 summarizes the results of a number of previous SBRT studies at large academic institutions and clinical trials.

There are only a limited number of studies using CyberKnife in the treatment of stage I NSCLC. CyberKnife therapy appears to have similar success for local control and overall survival to other tools for delivering SBRT. The local control with CyberKnife therapy is reported from 85.8 to $100 \%$ and the overall survival is reported from 45 to $87 \%(12-16)$. A number of previous

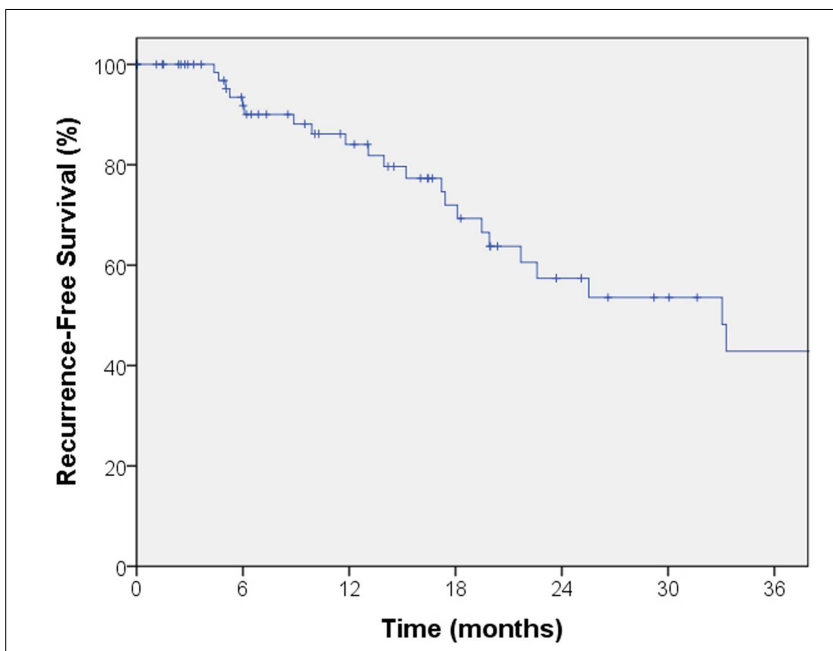

FIGURE 3 | Kaplan-Meier curve for recurrence-free survival. There were 25 cases of recurrence of any form. The 2-year recurrence-free survival was $48.3 \%$.

Table 2 | Univariate analysis of predictors of local control and overall survival.

\begin{tabular}{|c|c|c|c|c|c|}
\hline & & \multicolumn{2}{|c|}{ Local control } & \multicolumn{2}{|c|}{ Overall survival } \\
\hline & & $\begin{array}{l}2 \text { years } \\
\text { LC }(\%)\end{array}$ & $p$-Value & $\begin{array}{l}2 \text { years } \\
\text { OS (\%) }\end{array}$ & $p$-Value \\
\hline \multirow[t]{2}{*}{ Gender } & Male & 78 & 0.23 & 57 & 0.009 \\
\hline & Female & 92 & & 77 & \\
\hline \multirow[t]{2}{*}{ Age } & $<75$ & 92 & 0.43 & 64 & 0.59 \\
\hline & $\geq 75$ & 85 & & 70 & \\
\hline \multirow[t]{2}{*}{ Histology } & Adeno & 95 & 0.54 & 74 & 0.2 \\
\hline & SCC & 83 & & 60 & \\
\hline \multirow[t]{2}{*}{ TNM } & T1N0M0 & 90 & 0.15 & 68 & 0.66 \\
\hline & T2NOMO & 82 & & 68 & \\
\hline \multirow[t]{2}{*}{$\operatorname{BED}\left(\mathrm{Gy}_{10}\right)$} & $\leq 106 \mathrm{~Gy}$ & 85 & 0.36 & 60 & 0.85 \\
\hline & $>106 \mathrm{~Gy}$ & 92 & & 76 & \\
\hline
\end{tabular}

CyberKnife studies are included in Table 4. The study by Vahdat et al. included in Table 4 only included patients with stage IA NSCLC.

Our study found comparable local control and overall survival to previous CyberKnife studies in the treatment of stage I NSCLC. Our study has a comparable or superior sample size to many of the previous CyberKnife studies.

The correlation between overall survival and gender is not unique to our study. In a single institutional prospective study of 177 patients with potentially operable stage I NSCLC, Lagerwaard et al. found female gender to have superior overall survival $(p=0.02)$ on multivariate analysis (8). Lagerwaard did not find a correlation between overall survival and any other patient, tumor, or treatment characteristic. 
Table 3 | Results of previous SBRT studies at large institutions and clinical trials.

\begin{tabular}{lclll}
\hline Study & $\begin{array}{l}\text { Number of } \\
\text { patients }\end{array}$ & $\begin{array}{l}\text { Median } \\
\text { follow-up } \\
\text { (months) }\end{array}$ & $\begin{array}{l}\text { 3-year } \\
\text { Local } \\
\text { control }\end{array}$ & $\begin{array}{l}\text { 3-year } \\
\text { Overall } \\
\text { survival }\end{array}$ \\
\hline $\begin{array}{l}\text { Timmerman et al. } \\
\text { (RTOG 0236) (6) }\end{array}$ & 55 & 34.4 & $90.6 \%$ & $55.8 \%$ \\
Baumann et al. (7) & 57 & 34.0 & $92.0 \%$ & $60.0 \%$ \\
Crabtree et al. (4) & 151 & 23.4 & $90.0 \%$ & $47.0 \%$ \\
Lagerwaard et al. (8) & 177 & LC-20.0 & $93.0 \%$ & $84.7 \%$ \\
& & OS-31.5 & & \\
Shibamoto et al. (9) & 180 & 36.0 & $83.0 \%$ & $69.0 \%$ \\
Fakiris et al. (10) & 70 & 50.2 & $88.1 \%$ & $42.7 \%$ \\
Present study & 74 & LC-14.4 & $87.0 \%$ & $68.0 \%$ \\
& & OS-18.8 & $(2-y e a r)$ & $(2-y e a r)$ \\
\hline
\end{tabular}

Table 4 | Results of previous CyberKnife studies.

\begin{tabular}{|c|c|c|c|c|}
\hline Study & $\begin{array}{l}\text { Number of } \\
\text { patients }\end{array}$ & $\begin{array}{l}\text { Median } \\
\text { follow-up } \\
\text { (months) }\end{array}$ & $\begin{array}{l}\text { 2-year } \\
\text { Local } \\
\text { control }\end{array}$ & $\begin{array}{l}\text { 2-year } \\
\text { Overall } \\
\text { survival }\end{array}$ \\
\hline Chen et al. (12) & 40 & 44.0 & $\begin{array}{l}91.0 \% \\
\text { (3-year) }\end{array}$ & $\begin{array}{l}45.0 \% \\
\text { (3-year) }\end{array}$ \\
\hline Collins et al. (13) & 20 & 25.0 & $100 \%$ & $87.0 \%$ \\
\hline $\begin{array}{l}\text { van der Voort } \\
\text { van Zyp et al. } \\
\text { (14) }\end{array}$ & $\begin{array}{l}60 \text { Gy-59 } \\
45 \text { Gy-11 } \\
70 \text { Total }\end{array}$ & 15.0 & $\begin{array}{l}60 \mathrm{~Gy}-96.0 \% \\
45 \mathrm{~Gy}-78.0 \%\end{array}$ & $\begin{array}{l}62.0 \% \text {-all } \\
\text { patients }\end{array}$ \\
\hline Brown et al. (15) & 31 & 27.5 & $\begin{array}{l}85.8 \% \\
\text { (4.5-year) }\end{array}$ & $\begin{array}{l}83.5 \% \\
\text { (4.5-year) }\end{array}$ \\
\hline Vahdat et al. (16) & 20 & 43.0 & $95.0 \%$ & $90.0 \%$ \\
\hline Present study & 74 & $\begin{array}{l}\text { LC-14.4 } \\
\text { OS-18.8 }\end{array}$ & $87.0 \%$ & $68.0 \%$ \\
\hline
\end{tabular}

Similarly, in a multicenter study involving 180 stage I NSCLC patients, Shibamoto et al. found women to have an overall survival of $86 \%$ and men to have an overall survival of $67 \%(p=0.031)$ (9). This study also found women as well as younger patients to have more favorable local recurrence rates. The $p$-value was 0.027 for women and 0.014 for age $\leq 76$.

The link between female gender and superior overall survival does not appear to be unique to SBRT. A study by Wilsnivesky and Halm involving 18,967 elderly patients with stage I and II NSCLC divided patients into those receiving surgery, those receiving chemotherapy or radiation but not surgery, and untreated patients (17). Women were found to have better overall survival than men in all three groups $(p<0.001)$. On multivariate analysis women had better overall survival regardless of treatment type. Potential explanations for better overall survival of females included hormonal, genetic, and metabolic factors.
Other studies have demonstrated dose to correlate with local control and overall survival $(18,19)$. In a retrospective study involving 257 patients with stage I NSCLC at 14 institutions, Onishi et al. found those treated with a $\mathrm{BED}_{10 \mathrm{~Gy}}$ of $100 \mathrm{~Gy}$ or more to have statistically significant superior local control and overall survival to patients receiving a $\mathrm{BED}_{10 \mathrm{~Gy}}$ of $<100 \mathrm{~Gy}$ (18). Olsen et al. also found improved local control and overall survival when treated with a $\mathrm{BED}_{10 \mathrm{~Gy}}$ of $>100 \mathrm{~Gy}$ in a single-center study of 130 patients with early-stage NSCLC (18).

In a study of 505 patients with early-stage NSCLC, Grills et al. found a $\mathrm{BED}_{10 \mathrm{~Gy}}$ of $105 \mathrm{~Gy}$ or greater to predict local control (20). In this study, local recurrence was $15 \%$ in patients treated with a $\mathrm{BED}_{10 \mathrm{~Gy}}$ of $<105 \mathrm{~Gy}$ and $4 \%$ in patients receiving a $\mathrm{BED}_{10 \mathrm{~Gy}}$ of $105 \mathrm{~Gy}$ or greater $(p<0.0001)$. In our study, a $\mathrm{BED}_{10 \mathrm{~Gy}}$ of greater than or less than 106 likely failed to correlate with local control because of the smaller sample size of our study.

This study is limited by its relatively small sample size, short follow-up period, and retrospective design. As in the case of $\mathrm{BED}_{10 \mathrm{~Gy}}$, it is possible that some of the variables may have achieved statistical significance with a larger sample size.

In conclusion, our study at a small academic hospital demonstrates effective local control and overall survival of patients with stage I NSCLC treated with SBRT. These results are encouraging for the use of CyberKnife SBRT in the treatment of stage I NSCLC outside of major academic institutions.

\section{REFERENCES}

1. National Comprehensive Cancer Network. Non-Small Cell Lung Cancer (Version 3.2014) (2014). Available form: http://www.nccn.org/professionals/physician_ gls/pdf/nscl.pdf

2. Sugi K, Kaneda Y, Esato K. Video-assisted thoracoscopic lobectomy achieves a satisfactory long-term prognosis in patients with clinical stage IA lung cancer. World J Surg (2000) 24(1):27-30. doi:10.1007/s002689910006

3. Flores RM, Ihekweazu UN, Rizk N, Dycoco J, Bains MS, Downey RJ, et al. Patterns of recurrence and incidence of second primary tumors after lobectomy by means of video-assisted thoracoscopic surgery (VATS) versus thoracotomy for lung cancer. J Thorac Cardiovasc Surg (2011) 141(1):59-64. doi:10.1016/j.jtcvs.2010.08.062

4. Crabtree TD, Puri V, Robinson C, Bradley J, Broderick S, Patterson GA, et al. Analysis of first recurrence and survival in patients with stage I non-small cell lung cancer treated with surgical resection or stereotactic radiation therapy. J Thorac Cardiovasc Surg (2014) 147(4):1183-91. doi:10.1016/j.jtcvs.2013.11. 057

5. Dosoretz DE, Katin MJ, Blitzer PH, Rubenstein JH, Galmarini DH, Garton GR, et al. Medically inoperable lung carcinoma: the role of radiation therapy. Semin Radiat Oncol (1996) 6(2):98-104. doi:10.1053/SRAO00600098

6. Timmerman R, Paulus R, Galvin J, Michalski J, Straube W, Bradley J, et al. Stereotactic body radiation therapy for inoperable early stage lung cancer. JAMA (2010) 303(11):1070-6. doi:10.1001/jama.2010.261

7. Baumann P, Nyman J, Hoyer M, Wennberg B, Gagliardi G, Lax I, et al. Outcome in a prospective phase II trial of medically inoperable stage I non-small-cell lung cancer patients treated with stereotactic body radiotherapy. J Clin Oncol (2009) 27(20):3290-6. doi:10.1200/JCO.2008.21.5681

8. Lagerwaard FJ, Verstegen NE, Haasbeek CJ, Slotman BJ, Paul MA, Smit EF, et al. Outcomes of stereotactic ablative radiotherapy in patients with potentially operable stage I non-small cell lung cancer. Int J Radiat Oncol Biol Phys (2012) 83(1):348-53. doi:10.1016/j.ijrobp.2011.06.2003

9. Shibamoto Y, Hashizume C, Baba F, Ayakawa S, Manabe Y, Nagai A, et al. Stereotactic body radiotherapy using a radiobiology-based regimen for stage I nonsmall cell lung cancer: a multicenter study. Cancer (2012) 118(8):2078-84. doi: $10.1002 / \mathrm{cncr} .26470$

10. Fakiris AJ, McGarry RC, Yiannoutsos CT, Papiez L, Williams M, Henderson MA, et al. Stereotactic body radiation therapy for early-stage non-small-cell lung 
carcinoma: four-year results of a prospective phase II study. Int J Radiat Oncol Biol Phys (2009) 75(3):677-82. doi:10.1016/j.ijrobp.2008.11.042

11. Nagata Y, Takayama K, Matsuo Y, Norihisa Y, Mizowaki T, Sakamoto T, et al. Clinical outcomes of a phase I/II study of 48 Gy of stereotactic body radiotherapy in 4 fractions for primary lung cancer using a stereotactic body frame. Int J Radiat Oncol Biol Phys (2005) 63(5):1427-31. doi:10.1016/j.ijrobp. 2005.05.034

12. Chen VJ, Oermann E, Vahdat S, Rabin J, Suy S, Yu X, et al. CyberKnife with tumor tracking: an effective treatment for high-risk surgical patients with stage I non-small cell lung cancer. Front Oncol (2012) 2:9. doi:10.3389/fonc.2012.00009

13. Collins BT, Vahdat S, Erickson K, Collins SP, Suy S, Yu X, et al. Radical CyberKnife radiosurgery with tumor tracking: an effective treatment for inoperable small peripheral stage I non-small cell lung cancer. J Hematol Oncol (2009) 2:1. doi:10.1186/1756-8722-2-1

14. van der Voort van Zyp NC, Prevost JB, Hoogeman MS, Praag J, van der Holt B, Levendag PC, et al. Stereotactic radiotherapy with real-time tumor tracking for non-small cell lung cancer: clinical outcome. Radiother Oncol (2009) 91(3):296-300. doi:10.1016/j.radonc.2009.02.011

15. Brown WT, Wu X, Fayad F, Fowler JF, Garcia S, Monterroso MI, et al. Application of robotic stereotactic radiotherapy to peripheral stage I non-small cell lung cancer with curative intent. Clin Oncol (2009) 21(8):623-31. doi:10.1016/ j.clon.2009.06.006

16. Vahdat S, Oermann EK, Collins SP, Yu X, Abedalthagafi M, Debrito P, et al. CyberKnife radiosurgery for inoperable stage IA non-small cell lung cancer: $18 \mathrm{~F}$ fluorodeoxyglucose positron emission tomography/computed tomography serial tumor response assessment. J Hematol Oncol (2010) 3:6. doi:10.1186/17568722-3-6

17. Wisnivesky JP, Halm EA. Sex differences in lung cancer survival: do tumors behave differently in elderly women? J Clin Oncol (2007) 25(13):1705-12. doi:10.1200/JCO.2006.08.1455

18. Onishi H, Shirato H, Nagata $Y$, Hiraoka M, Fujino $M$, Gomi $K$, et al. Hypofractionated stereotactic radiotherapy (HypoFXSRT) for stage I non-small cell lung cancer: updated results of 257 patients in a Japanese multiinstitutional study. J Thorac Oncol (2007) 2(7 Suppl 3):S94-100. doi:10.1097/ JTO.0b013e318074de34

19. Olsen JR, Robinson CG, El Naqa I, Creach KM, Drzymala RE, Bloch C, et al. Dose-response for stereotactic body radiotherapy in early-stage nonsmall-cell lung cancer. Int J Radiat Oncol Biol Phys (2011) 81(4):e299-303. doi:10.1016/j.ijrobp.2011.01.038

20. Grills IS, Hope AJ, Guckenberger M, Kestin LL, Werner-Wasik M, Yan D, et al. A collaborative analysis of stereotactic lung radiotherapy outcomes for early-stage non-small-cell lung cancer using daily online cone-beam computed tomography image-guided radiotherapy. J Thorac Oncol (2012) 7(9):1382-93. doi:10.1097/JTO.0b013e318260e00d

Conflict of Interest Statement: Dr. Jonathan A. Haas has received speaker's honoraria from Accuray, Inc., Sunnyvale, CA, USA. The other co-authors declare that the research was conducted in the absence of any commercial or financial relationships that could be construed as a potential conflict of interest.

Received: 16 July 2014; accepted: 05 October 2014; published online: 20 October 2014. Citation: Factor OB, Vu CC, Schneider JG, Witten MR, Schubach SL, Gittleman AE, Catell DT and Haas JA (2014) Stereotactic body radiation therapy for stage I nonsmall cell lung cancer: a small academic hospital experience. Front. Oncol. 4:287. doi: 10.3389/fonc. 2014.00287

This article was submitted to Radiation Oncology, a section of the journal Frontiers in Oncology.

Copyright () 2014 Factor, Vu, Schneider, Witten, Schubach, Gittleman, Catell and Haas. This is an open-access article distributed under the terms of the Creative Commons Attribution License (CC BY). The use, distribution or reproduction in other forums is permitted, provided the original author(s) or licensor are credited and that the original publication in this journal is cited, in accordance with accepted academic practice. No use, distribution or reproduction is permitted which does not comply with these terms. 